\title{
What Influences Bank Stock Prices in Times of Crisis? An International Survey
}

\author{
Elisabetta D'Apolito ${ }^{1} \&$ Vincenzo Pacelli ${ }^{1}$ \\ ${ }^{1}$ Department of Economics, University of Foggia, Foggia, Italy \\ Correspondence: Elisabetta D’Apolito, Department of Economics, University of Foggia, Foggia, 71121, Italy. \\ Tel: 39-0881-781731. E-mail: elisabetta.dapolito@unifg.it
}

Received: March 22, 2017

Accepted: April 11, 2017

Online Published: May 5, 2017

doi:10.5539/ijef.v9n6p1

URL: https://doi.org/10.5539/ijef.v9n6p1

\begin{abstract}
The paper assesses whether the European banks' stock prices are predicted or affected by changes in balance-sheet indicators and macroeconomic variables. The sample covers the time period from January 2007 to December 2013. Estimates use the multiple regression model based on the weighted least squares (WLS) estimator. Results show that the stock prices of European banks are positively related to asset quality, liquidity and banks' capital ratios. However, in the same period, inflation rate and public debt exert a negative and significant effect on bank stock prices. Our findings are more significant in times of high market turbulence as have been experienced for almost a decade. These have provoked the investors' perceptions to be more unstable and volatile. The availability of information remains limited and poor. Therefore, it is necessary to emphasize that identifying the causal determinants of stock prices in the markets could generate important practical and policy implications because of the role played by banks in financing the economic system, and will also attract investors (Note 1).
\end{abstract}

Keywords: stock prices, banking, bank-specific accounting indicators, crisis

\section{Introduction}

What influences the dynamics of bank stock prices? To address this question, economic research has explored many avenues in an attempt to find an answer. Studies have produced conflicting empirical evidence over a period of time, with various samples and analysis methodology. The global financial crisis sparked a renewed interest in this topic by those involved in the policy debate.

According to Warren Buffet, "the price is what you pay, value is what you get", but those assumptions are not always represented as such in financial markets. In particular, with regard to listed companies, at least one significant deviation frequently occurs between the market value (which represents the price of the company) and the economic value listed. For many years, the evolution of company share prices listed on major international markets did not seem to reflect the dynamics of the value of their economic capital or those of shareholders' capital. This is true when considering the varying differences of quoted companies and also banks. These companies are particularly vulnerable in times of crisis and uncertainty, such as the current times. The differences between the market value and the economic value of a bank originate, in part, with systemic factors that are not directly controllable by the management. In phases of economic expansion, the differential is very often blatantly in favor of market prices, while in phases of depressed stock prices, market capitalizations often express significant reductions of value in comparison to economic capital and shareholders. It would, however, be simplistic and superficial (as well as barely significant from a management perspective) to restrict the analysis to economic factors. Evidence from international financial markets shows numerous cases of similar companies, i.e. operating in the same industry with similar fundamental economic and financial factors, that are characterized by dramatically different market values. Consider, by way of example and always with reference to the banking sector, the two cases of Lehman Brothers and Unicredit which, by the end of summer 2008, had been the target of international financial speculation, while having basic financial numbers similar to those of other banks operating in the same sectors. In the case of Lehman Brothers, the speculative attack led to their bankruptcy, even though it had at the time of default a turnover of about 640 billion dollars in capital assets (valued in the financial statements for that value and certified by rating). Its economic and financial variables were no worse than those of other US investment banks. Unicredit managed to overcome the dramatic price 
collapse of its share price, recapitalizing and evidently regaining credibility in the markets. Lehman Brothers and its management did not manage. This suggests that the market discriminates against different companies based on specific variables, which are invisible to an analysis based purely on accounting. It should at all times be considered what the prices of securities on the market reflect. Predictions of the future potential income of an individual company are based on the result of the market comparison between the demand and supply of the stock itself (Fama, 1970; Campbell \& Kracaw, 1980; Millon \& Thakor, 1985). In this sense, stock prices incorporate the information and expectations of market participants on the fundamental economic variables that determine the value of the securities and are, for that reason, one of the predictable values that can be generated by the proxy (Chan \& Thakor, 1987; Allen, 1990). Therefore, any difference between the estimated economic capital produced by the market and that deduced from the accounting data, highlights a different assessment of the enterprise asset market, namely that the presence of tags and invisible assets are used to read a company's financial statements. They are then considered and valued, positively or negatively, by the market. The feedback produced by the market in the economic capital of the listed companies is strongly influenced by factors that are essentially emotionally motivated and, therefore, ephemeral. Beyond the effects produced by the changing economic times, it is reasonable to assume that the significant emerging differences between the market and economic values of the listed banks' capitals reflect market perceptions influenced by business factors that often go beyond the economic fundamentals of the same enterprises (Keynes, 1936; Modigliani, 1958; Salvatore, 2001). This refers to factors of a purely intangible and invisible nature, namely market perceptions, that influence economic outlook over a more or less broad time horizon. Empirical evidence shows (Pacelli, 2007) that stock prices are often ultimately influenced by speculative bubbles, transitional trends or intangibles, which causes a discrepancy between the fundamental value of the share and the stock price actually traded in the market.

This research aims to analyze which variables influence bank stock prices by empirically investigating a panel of European banks from a period of sustained growth to the beginning and the evolution of the financial crisis. In particular the sample covers the time period from January 2007 to December 2013.The two research questions that this paper intends to answer are the following: in a period of market uncertainty and turbulence, which variables (systemic, macroeconomic, market variables or balance-sheet indicators) influence bank stock prices? Additionally, in times of crisis, are markets able to predict future corporate and economic phenomena that can influence stock prices? These research questions are even more significant in times of high market turbulence as have been experienced for almost a decade. These have provoked the investors' perceptions to be more unstable and volatile. The availability of information remains limited and poor. Therefore, it is necessary to emphasize that identifying the causal determinants of stock prices in the markets could generate important practical and policy implications because of the role played by banks in financing the economic system, and will also attract investors.

This work aims to contribute to the existing literature on the subject and several aspects of it differ from previous studies.

First, unlike in previous research whose dependent variable is some country's bank stock return, here the price-to-book value ratio of the European banks' stock is studied.

Second, panel data analysis combined micro and macro-economic variables together as independent variables in order to disclose the dynamic of dependent variable, while being aware that the formation of stock prices is based on other fundamentally important variables, such as corporate events and happenings and joint works, which are difficult to measure.

Third, estimates use the multiple regression model based on the weighted least squares (WLS) estimator. The results show that the stock prices of European banks are positively related to asset quality, liquidity and banks' capital ratios. However, in the same period, inflation rate and public debt exert a negative and significant effect on bank stock prices.

The remainder of the paper is organized as follows. Section 2 provides a concise review of the literature on the topic under discussion. Section 3 describes the research methodology used. Section 4 illustrates empirical evidence emerging from the analysis and Section 5 concludes.

\section{Literature Review}

The study of the dynamics of share prices assumes even more importance in times of crisis of confidence, uncertainty and high market volatility (Brana \& Prat, 2016; Küçükkocaoğlua et al., 2013; Chronopoulos et al., 2013). The price of a share is affected, to an extent and with differing intensity, by all the variables that determine its supply and demand. 
In general terms, it is therefore reasonable to assume that the investment decisions of market participants are influenced by a large set of explanatory variables that determine the demand for shares in the market (Kasmana et al., 2011). The process of formation of the application of actions of a generic listed company (and therefore also of a bank) was analyzed in the literature with a focus on both micro- and macro-economies, using different methodologies and variables.

From a micro-economic approach, the empirical research focuses on the examination of the internal nature of the variables of the economic and financial firms listed, which are essentially seen as the main financial indicators, that are then evaluated to derive a prospective balance. Cantor and Johnson (1992) identify, through an econometric methodology, a direct and significant relationship between increases in capital (Tier 1 and total capital) and the prospects of return of stock. Similarly, various studies (Beccalli et al., 2006; Chu \& Lim, 1998) through the use of parametric (such as the Stochastic Frontier Approach) and non-parametric techniques (such as the Data Envelopment Analysis method) show a positive relationship between some production efficiency variables (such as the cost to income ratio) and performance of bank shares. Other analyses (Lakonishok et al., 1994), conducted through the use of alternative regression models, such as the Capital Asset Pricing Model, evaluate whether the influence of a budgetary indicator on the share price remains even in the presence of adjustments for systematic risk factors attributable to differences in the risk threat of banks. These analyses show that the variables that best explain the market price of the stock exchange banks are profitability (ROE) and liquidity (interbank position), rather than those relating to the degree of capitalization (solvency ratio). Recent empirical evidence (Macit \& Topaloğlu, 2012) also reports a misalignment between the book value and the market value of the shares, especially for banks that have a financial activities budget that has already been assessed at market prices. Therefore, this misalignment can be attributed to the expectations of investors that the bank management generates less value than does accounting. In fact, in times of financial crisis the market may evaluate the share price at an even lower value than the book, because the prices of bank shares may incorporate an inability by the bank to create value.

From a macro-economic perspective, the goal of empirical research is to analyze market variables, such as the evolution of the economic situation, the inflation trend, the change preferences and investor confidence (Akella \& Greenbaum, 1992; Lajeri \& Dermine, 1999; Durai \& Bhaduri, 2009). A macro-economic variable to be monitored, one which can produce a significant impact on the trend of stock prices, is the growth of GDP, which measures the value of final goods and services produced or provided in a particular country within a period of time (Beck \& Ross, 2004; Duca, 2007). This is the main measure of economic activity and wealth produced by a country. These analyses show a direct and positive relationship between economic growth and stock price. Therefore deterioration of the economic situation could have an adverse effect on the stock prices and vice versa. Among the external variables, it should be noted, is also the explanatory power of the inflation rate and its connection with the stock price, a relationship that has for years been the subject of study and debate in economic literature. On this issue, some studies conducted by econometric methods demonstrate the neutrality of the inflation phenomenon or the average positive relationship between stock prices and inflation (Giliberto, 1985; Saunders \& Yourougou, 1990; Choi et al., 1992) of stocks representing capital with returns, in real terms, that do not vary with inflation. However, a second line of research arrives at different conclusions, highlighting, with the regression method, that inflation has a depressive effect on the price of securities (Dermine, 1985; Perry, 1992; Merikas \& Merika, 2006) as it affects some variables, such as risk or other real variables, which depress the value of stock prices. Lastly, in periods of financial crisis, various studies (Wolff, 2011; Mody \& Sandri, 2011) have analyzed the impact of countries with high debt-to-GDP ratios and their banking system. This analysis shows that banks' market valuations were not affected by the holding of government debt by Italy, Spain, Portugal and Ireland. Finally, statistical analyses (Flannery \& James, 1984; Czaja et al., 2009) find that bank stock returns are more sensitive to interest rate changes than the stock returns of other companies.

\section{Data and Methodology}

\subsection{Data and Variable Definitions}

The study aimed to analyze: (i) whether the share prices of banks reflect the dynamics of the financial ratios and variables of the stock market and macroeconomics; (ii) whether, in times of crisis, business and economic circumstances are able to influence the prices of securities.

The empirical analysis focuses on major European banks and the amount of managed assets, from December 2013. The sample is composed of 50 important listed European banks based on the volume of activity belonging to different geographical areas (Table 1). In terms of managed assets, the Anglo-Saxon banks (6 British banks and 2 Irish banks) manage overall almost $33.6 \%$ of total assets attributable to the whole sample of examined 
banks. They are followed by French banks with $18 \%$ of managed assets, by German and Spanish with 11\%, Italian with 10\%, Swedish with 7\%, Danish with 3\%, Austrian and Greek with 2\%, Belgian and Portuguese with $1 \%$, and Finnish and Dutch with $0.2 \%$. Sources of data were the Bankscope and Datastream database, and the period of analysis is $2007-2013$.

Table 1. Sample composition (Total Assets in millions of euro)

\begin{tabular}{|c|c|c|c|c|c|}
\hline Name & Nation & $\begin{array}{l}\text { Total Assets } \\
31.12 .2013\end{array}$ & Name & Nation & $\begin{array}{l}\text { Total Assets } \\
31.12 .2013\end{array}$ \\
\hline HSBC & UK & 1.937 .001 & Banco Popolare & Italy & 126.043 \\
\hline BNP Paribas & France & 1.800 .139 & UBI Banca & Italy & 124.242 \\
\hline Deutsche Bank AG & Germany & 1.611 .400 & Allied Irish Banks plc & Ireland & 117.734 \\
\hline Barclays & UK & 1.574 .028 & National Bank of Greece & Greece & 110.930 \\
\hline Société Générale & France & 1.235 .262 & Piraeus Bank SA & Greece & 92.010 \\
\hline Royal Bank of Scotland & UK & 1.232 .911 & $\begin{array}{l}\text { Banco Comercial } \\
\text { Português }\end{array}$ & Portugal & 82.007 \\
\hline Banco Santander & Spain & 1.115 .638 & Banco Espirito Santo & Portugal & 80.608 \\
\hline Lloyds Banking & UK & 1.015 .989 & Eurobank Ergasias SA & Greece & 77.586 \\
\hline Unicredit & Italy & 845.838 & Alpha Bank AE & Greece & 73.697 \\
\hline Nordea Bank & Sweden & 630.434 & Mediobanca SpA & Italy & 72.841 \\
\hline Intesa San Paolo & Italy & 626.283 & Bankinter SA & Spain & 55.136 \\
\hline Banco Bilbao VA & Spain & 582.575 & Banca Popolare di Milano & Italy & 49.353 \\
\hline Commerzbank AG & Germany & 549.661 & Pohjola Bank plc & Finland & 43.720 \\
\hline Natixis & France & 510.131 & Aareal Bank AG & Germany & 42.981 \\
\hline Standard Chartered Plc & UK & 489.000 & Banco BPI SA & Portugal & 42.700 \\
\hline Danske Bank & Denmark & 432.622 & Banca Carige SpA & Italy & 42.156 \\
\hline $\begin{array}{l}\text { Skandinaviska Enskilda } \\
\text { Banken }\end{array}$ & Sweden & 280.484 & Jyske Bank A/S (Group) & Denmark & 35.124 \\
\hline Svenska Handelsbanken & Sweden & 280.471 & Banca Popolare di Sondrio & Italy & 32.770 \\
\hline KBC Groep & Belgium & 241.306 & Credito Emiliano & Italy & 31.531 \\
\hline Swedbank & Sweden & 205.902 & Investec Plc & UK & 28.798 \\
\hline Erste Group Bank AG & Austria & 199.876 & Credito Valtellinese & Italy & 27.199 \\
\hline Banco de Sabadell SA & Spain & 163.442 & DVB Bank SE & Germany & 23.363 \\
\hline Banco Popular Espanol & Spain & 147.852 & Sydbank A/S & Denmark & 19.827 \\
\hline Bank of Ireland & Ireland & 132.137 & Van Lanschot NV & Netherlands & 17.670 \\
\hline Raiffeisen Bank International & Austria & 130.640 & Oberbank AG & Austria & 17.571 \\
\hline
\end{tabular}

The process of share price formation is investigated in the period 2007-2013, through the multiple regression model in which the share price (dependent variable), measured by the ratio price-to-book value $(\mathrm{P})$ average annual (Note 2), is a function of different variables (independent), both internal and external to the bank, or market and macroeconomic. The quotient $\mathrm{P}$ allows dynamic identification and assessment of how the market contributes to the economic capital of the bank, since the market value of an asset reflects its yield potential and its expected cash flows, while the book value provides a comparatively rather stable measurement of the same heritage. This presents, in succession, the graph of the P median, by country, of the sample over the period. Italy has a much lower index median value than other European countries (0.51). 


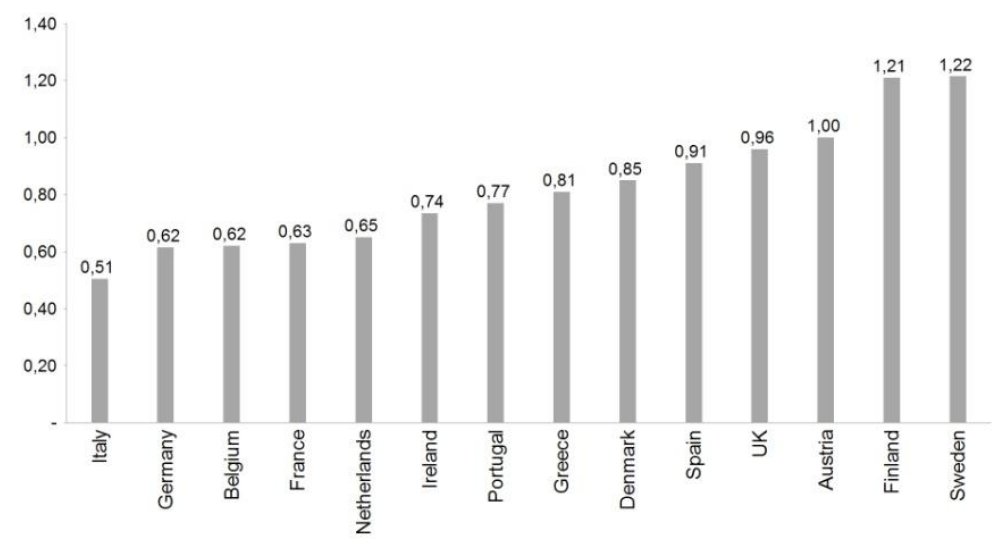

Figure 1. The median Price-to-book value of banks

The analytical description of the individual independent variables considered is indicated in Table 2.

Table 2. The bank variables considered in the analysis

\begin{tabular}{lll}
\hline Symbol & Indicator & Measurement \\
\hline LLP/NIR & Loan loss provisions / Net interest revenue & Quality of investments \\
NL/D & Net loans / Deposits \& short-term funding & Operations \\
NL/TA & Net loans / Total assets & Operations \\
T1 & Tier 1 ratio & Degree of capitalization \\
REP & Recurring earning power & Operating profitability \\
ROAA & Return on average assets & Operating profitability \\
IR & Interbank ratio & Degree of liquidity \\
I & Annual average rate of inflation & Macroeconomic analysis \\
PD\%GDP & Public debt in \% Gdp & Macroeconomic analysis \\
GDPG & GDP growth & Control \\
EYCI & Euro yield curve Index & Control \\
\hline
\end{tabular}

In regards to the choice of independent variables, the emphasis is primarily placed on some company-internal variables that, based on the previous studies, are believed to be causal determinants of the price dynamics of bank shares.

The first factor considered to determine the quality of investments is a flow indicator of reserves, which is measured by the ratio Loan loss provisions/Net interest revenue and has been extensively studied in the previous studies (Lancaster et al., 1993; Whalen, 1994; Docking et al., 1997) and exerts a significant impact on stock prices. The expected effects are not unique, as it depends on the portfolio management policy adopted and the market's assessment of the impact of risks. Increases in provisions for doubtful debts in relation to net interest income could negatively affect the stock price if interpreted by investors as an unexpected sign of the deterioration of banks' credit quality or, vice versa, be interpreted as a prudent maneuver to appreciate.

This paper considers other indicators such as the ratios Net Loans/Deposits \& short term funding and Net loans/Total assets with findings from previous studies (Cooper et al., 2003) that analyze operators' perceptions of the diversification policies adopted by banks. Regarding the level of capitalization, measured by the Tier 1 ratio, some studies (Cantor \& Johnson, 1992) generally show a positive relationship with stock prices. This is consistent with the expectation that capital increases encourage secure operators' perceptions with positive knock-on effects in terms of share prices. It is anticipated that the operating profitability of banks may affect investors' choices. Therefore the ratio between net income and average total balance sheet assets, defined as Return on average assets, is considered sufficient to quantify the return on the invested capital or the activity performed (Mohanty \& Song, 2002). A further indicator of profitability is Recurring earning power, that is the relationship between the incidence of the amount of profits before tax and provisions to loans and total assets, used as the dependent variable in this research. It has been included in this study as an indicator of liquidity, such as interbank ratio, that is the ratio of current account balances and debit balances in relationships with other banks, assuming a direct and significant relationship to the prices of securities on the market. In addition to bank 
company-internal variables (microeconomic perspective), stock prices can also be influenced by trends in the market in which the bank operates (macroeconomic perspective). Thus the impact that certain market and macroeconomic variables, such as the inflation rate and public debt as a percentage of gross domestic product (GDP), may have on stock prices can be analyzed. A number of control variables have also been considered, such as economic growth in the bank's home country and specifically the growth of GDP, as well as the slope of the yield curve, as key factors in the determination of bank profitability, while keeping in mind that not all banks are outside the Eurozone.

The descriptive statistics of the variables used in the analysis are shown in Table 3 (Note 3).

Table 3. Summary statistics of the explanatory variables

\begin{tabular}{lcccc}
\hline Variable & Mean & Std. Dev. & Min & Max \\
\hline P & 0.940 & 0.807 & -2.350 & 9.560 \\
LLP/NIR & 40.811 & 48.699 & -26.410 & 580.580 \\
NL/D & 99.485 & 32.886 & 26.190 & 218.390 \\
NL/TA & 58.217 & 24.845 & 10.332 & 327.630 \\
T1 & 10.391 & 3.042 & -6.100 & 20.300 \\
REP & 1.056 & 0.556 & -0.920 & 2.790 \\
ROAA & 0.197 & 1.306 & -12.370 & 4.430 \\
IR & 76.231 & 67.238 & 3.570 & 669.990 \\
I & 2.123 & 1.223 & -1.700 & 4.700 \\
PD\%GDP & 82.559 & 33.432 & 24.000 & 174.900 \\
GDPG & -0.267 & 2.940 & -8.900 & 6.000 \\
EYCI & 1.444 & 1.530 & 0.050 & 3.990 \\
\hline
\end{tabular}

During the period examined the average value of the $\mathrm{P}$ of the shares of the surveyed banks approximates 1 . With regard to operating variables, growth on average is determined over the period examined. This also affirms the positive average change in the capital requirement of the examined banks and variability, particularly in regard to profitability and quality indicators of investments over other indicators. The liquidity requirements of the banks in the period examined also showed growing average values. Finally, it is to be noted the positive average values of the macroeconomic variables analyzed, with the exception of the economy performance indicator, namely GDP growth, following the most adverse economic scene after 2009. Prior to the development of multivariate regression analysis, the correlation between the investigated independent variables was tested and the results are reported in Table 4.

Table 4. Correlation matrix

\begin{tabular}{|c|c|c|c|c|c|c|c|c|c|c|c|c|}
\hline & $\mathrm{P}$ & LLP/NIR & NL/D & NL/TA & $\mathrm{T} 1$ & REP & ROAA & IR & I & PD\%GDP & GDPG & EYCI \\
\hline $\mathrm{P}$ & 1 & -0.150 & -0.161 & -0.047 & 0.056 & 0.333 & 0.379 & 0.121 & -0.086 & -0.140 & 0.214 & 0.208 \\
\hline LLP/NIR & & 1 & -0.021 & 0.038 & 0.017 & -0.181 & -0.459 & -0.176 & -0.170 & 0.331 & -0.322 & -0.275 \\
\hline NL/D & & & 1 & 0.481 & -0.161 & -0.138 & -0.005 & -0.148 & -0.030 & -0.002 & 0.001 & 0.095 \\
\hline NL/TA & & & & 1 & -0.256 & 0.064 & -0.016 & 0.045 & -0.025 & 0.099 & -0.024 & 0.111 \\
\hline $\mathrm{T} 1$ & & & & & 1 & 0.060 & 0.235 & -0.028 & -0.089 & -0.149 & 0.059 & -0.392 \\
\hline REP & & & & & & 1 & 0.393 & 0.135 & 0.105 & 0.004 & -0.021 & 0.117 \\
\hline ROAA & & & & & & & 1 & 0.043 & 0.015 & -0.311 & 0.366 & 0.221 \\
\hline IR & & & & & & & & 1 & 0.116 & -0.040 & 0.002 & 0.126 \\
\hline I & & & & & & & & & 1 & -0.056 & 0.256 & 0.328 \\
\hline PD\%GDP & & & & & & & & & & 1 & -0.407 & -0.341 \\
\hline GDPG & & & & & & & & & & & 1 & 0.339 \\
\hline EYCI & & & & & & & & & & & & 1 \\
\hline
\end{tabular}

\subsection{Regression Models}

The methodology presented in this study estimating two models of which the first is based on the absence of a time lag $t$ in equation (1) and the second with a time lag $t+1$ ("Price-to-book value" $t+1$ and $t$ independent variables) (2), given that the budget used as explanatory data for year $t$ are published in $t+1$ : 


$$
\begin{gathered}
P_{(i, t)}=\alpha_{i}+\beta_{1} L L P / N I R_{(i, t)}+\beta_{2} N L / D_{(i, t)}+\beta_{3} N L / T A_{(i, t)}+\beta_{4} T 1_{(i, t)}+\beta_{5} R E P_{(i, t)}+\beta_{6} R O A A_{(i, t)}+\beta_{7} I R_{(i, t)}+ \\
\beta_{8} I_{(i, t)}+\beta_{9} P D \% G D P_{(i, t)}+\beta_{10} G D P G_{(i, t)}+\beta_{11} E Y C I_{(i, t)}+\varepsilon_{(i, t)} \\
P_{(i, t+l)}=\alpha_{i}+\beta_{1} L L P / N I R_{(i, t)}+\beta_{2} N L / D_{(i, t)}+\beta_{3} N L / T A_{(i, t)}+\beta_{4} T 1_{(i, t)}+\beta_{5} R E P_{(i, t)}+\beta_{6} R O A A_{(i, t)}+\beta_{7} I R_{(i, t)}+\beta_{8} I_{(i, t)}+ \\
\beta_{9} P D \% G D P_{(i, t)}+\beta_{10} G D P G_{(i, t)}+\beta_{l l} E Y C I_{(i, t)}+\varepsilon_{(i, t)}
\end{gathered}
$$

The following table (Table 5) summarizes the results of the analysis of weighted regression (Weighted Least Square - WLS), conducted on panel data, showing the sign of the variables and their significance (Note 4).

Table 5. Regression weighted "P" of certain financial ratios and macroeconomic variables (2007-2013)

\begin{tabular}{lcc}
\hline & $\mathrm{P}_{(\mathrm{t})}$ & $\mathrm{P}_{(\mathrm{t}+1)}$ \\
\hline LLP/NIR & $0.002^{* * *}$ & $0.003^{* * *}$ \\
NL/D & -0.001 & -0.002 \\
NL/TA & 0.001 & 0.001 \\
T1 & 0.016 & 0.020 \\
REP & $0.321^{* * *}$ & $0.122^{* * *}$ \\
ROAA & $0.096^{* * *}$ & $0.086^{* * *}$ \\
IR & $0.001^{* *}$ & 0.0002 \\
I & $-0.079^{* * *}$ & 0.031 \\
PD\%GDP & $-0.003^{* * *}$ & $-0.005^{* * *}$ \\
GDPG & $0.032^{* * *}$ & -0.001 \\
EYCI & $0.097^{* * *}$ & 0.014 \\
\hline$A d j R^{2}$ (n. observations) & $0.363(350)$ & $0.250(300)$ \\
\hline
\end{tabular}

Note. $*$ denotes significance at $10 \%(\mathrm{p}<0.1), * *$ denotes significance at $5 \%(\mathrm{p}<0.05), * * *$ denotes significance at $1 \%(\mathrm{p}<0.01)$.

In Table 6 the same regressions as those in Table 5 are repeated, with the difference that dummy variables to control the country effect are taken into account to grasp structural differences between countries and also in business models adopted by banks or business regulations (Note 5).

Table 6. Regression weighted "P" of certain financial ratios and macroeconomic variables (2007-2013)

\begin{tabular}{lcc}
\hline & $\mathrm{P}_{(\mathrm{t})}$ & $\mathrm{P}_{(\mathrm{t}+1)}$ \\
\hline LLP/NIR & $0.002^{* * *}$ & $0.004 * * *$ \\
NL/D & -0.001 & -0.001 \\
NL/TA & 0.001 & 0.001 \\
T1 & $0.033^{* *}$ & $0.045^{* * *}$ \\
REP & $0.270^{* * *}$ & $0.143^{* *}$ \\
ROAA & $0.088^{* * *}$ & 0.037 \\
IR & 0.0004 & 6.816 \\
I & $-0.133^{* * *}$ & 0.036 \\
PD\%GDP & -0.0001 & $-0.011^{* * *}$ \\
GDPG & $0.041^{* * *}$ & -0.003 \\
EYCI & $0.151^{* * *}$ & 0.018 \\
UK & 0.279 & 0.138 \\
France & -0.023 & 0.276 \\
Germany & -0.102 & 0.258 \\
Spain & 0.190 & 0.175 \\
Italy & 0.048 & $0.630^{*}$ \\
Sweden & $0.395 *$ & 0.360 \\
Denmark & 0.141 & -0.099 \\
Belgium & -0.017 & 0.375 \\
Austria & 0.042 & 0.380 \\
Ireland & -0.109 & -0.163 \\
Greece & 0.237 & 0.469 \\
Portugal & 0.112 & $0.472 *$ \\
Finland & 0.416 & 0.308 \\
\hline Adj $R^{2}$ (n. observations) & $0.380(350)$ & $0.280(300)$ \\
\hline Note. ${ }^{*}$ denotes significance at $10 \%(\mathrm{p}<0.1), * *$ denotes & significance at $5 \%(\mathrm{p}<0.05), * * *$ denotes significance at $1 \%(\mathrm{p}<0.01)$
\end{tabular}


In Table 7 the same regressions are repeated for the following sub-sample of countries: Portugal, Italy, Ireland, Greece and Spain.

Table 7. Regression weighted "P" of certain financial ratios and macroeconomic variables (2007-2013)

\begin{tabular}{lcc}
\hline & $\mathrm{P}_{(\mathrm{t})}$ & $\mathrm{P}_{(\mathrm{t}+1)}$ \\
\hline LLP/NIR & $0.002^{* *}$ & $0.003^{* * *}$ \\
NL/D & -0.002 & -0.001 \\
NL/TA & -0.002 & -0.007 \\
T1 & 0.008 & 0.009 \\
REP & $0.296^{* * *}$ & 0.073 \\
ROAA & $0.098^{* *}$ & 0.072 \\
IR & 0.001 & 0.0003 \\
I & $-0.084 * *$ & 0.011 \\
PD\%GDP & -9.368 & $-0.003 * *$ \\
GDPG & $0.057^{* * * *}$ & $0.033^{* *}$ \\
EYCI & $0.154 * * *$ & 0.047 \\
\hline Adj $R^{2}$ (n. observations) & $0.391(168)$ & $0.276(144)$ \\
\hline
\end{tabular}

Note. $*$ denotes significance at $10 \%(\mathrm{p}<0.1), * *$ denotes significance at $5 \%(\mathrm{p}<0.05)$, *** denotes significance at $1 \%(\mathrm{p}<0.01)$.

\subsection{Model Selection}

In light of the recent financial crisis, the study was repeated in order to test the conclusions.

Table 8 presents the weighted regression on panel data of shares $\mathrm{P}$ on the balance sheet ratios and analyzed market and macroeconomic variables as well as on the control variables. The survey period has been split into years prior to the financial crisis and during the financial crisis (2007-2009) and subsequent years (2010-2013), characterized by the sovereign debt crisis.

Table 8. Multivariate Regression of "P" of the shares of certain financial ratios and macroeconomic variables during the pre-crisis, crisis and post-crisis periods

\begin{tabular}{lcc}
\hline & $\mathrm{P}_{(\mathrm{t})}$ & $\mathrm{P}_{(\mathrm{t}+1)}$ \\
& $2007-2009$ & $2010-2013$ \\
\hline LLP/NIR & -0.0003 & $0.003^{* * *}$ \\
NL/D & 0.0001 & 0.0001 \\
NL/TA & -0.001 & 0.002 \\
T1 & $0.037^{*}$ & 0.005 \\
REP & $0.143^{*}$ & $0.233^{* * *}$ \\
ROAA & $0.438^{* * *}$ & $0.063^{* *}$ \\
IR & $0.001^{* *}$ & 0.001 \\
I & -0.053 & 0.033 \\
PD\%GDP & $-0.003^{* *}$ & $-0.004^{* * *}$ \\
GDPG & $0.121^{* * *}$ & $0.049^{* *}$ \\
EYCI & $-0.158^{* *}$ & $-0.257^{* *}$ \\
\hline Adj $R^{2}$ (n. observations $)$ & $0.520(150)$ & $0.328(200)$ \\
\hline
\end{tabular}

Note. $*$ denotes significance at $10 \%(\mathrm{p}<0.1)$, ** denotes significance at $5 \%(\mathrm{p}<0.05)$, *** denotes significance at $1 \%(\mathrm{p}<0.01)$.

In Table 9 the same regressions as Table 8 are repeated, with the difference that, in this case, dummy variables are taken into account to control the effect on each country. 
Table 9. Multivariate Regression of "P" of the shares of certain financial ratios and macroeconomic variables in the pre-crisis, crisis and post-crisis periods

\begin{tabular}{|c|c|c|}
\hline & $\begin{array}{c}P_{(t)} \\
2007-2009 \\
\end{array}$ & $\begin{array}{c}P_{(t+1)} \\
2010-2013 \\
\end{array}$ \\
\hline LLP/NIR & -0.0003 & $0.001 * *$ \\
\hline NL/D & -0.0009 & 0.0001 \\
\hline NL/TA & -0.0002 & 0.003 \\
\hline $\mathrm{T} 1$ & $0.063 * *$ & 0.0001 \\
\hline REP & 0.004 & $0.304 * * *$ \\
\hline ROAA & $0.410 * * *$ & $0.098 * *$ \\
\hline IR & 0.001 & 0.0001 \\
\hline I & $-0.149 * * *$ & 0.027 \\
\hline PD\%GDP & $-0.043 * * *$ & $0.016^{* * *}$ \\
\hline GDPG & $0.115^{* * *}$ & $0.066^{* *}$ \\
\hline EYCI & $-0.233 * *$ & -0.173 \\
\hline UK & 0.461 & -0.045 \\
\hline France & $0.754 *$ & -0.180 \\
\hline Germany & 0.451 & -0.151 \\
\hline Spain & -0.023 & -0.020 \\
\hline Italy & $2.545^{* * *}$ & $-0.928 * *$ \\
\hline Sweden & -0.223 & $0.981 * * *$ \\
\hline Denmark & -0.594 & $0.693 * *$ \\
\hline Belgium & $1.985 * * *$ & $-0.797 *$ \\
\hline Austria & $0.930^{* *}$ & -0.268 \\
\hline Ireland & 0.032 & -0.255 \\
\hline Greece & $3.108^{* * *}$ & $-1.391 * *$ \\
\hline Portugal & $1.166^{* * *}$ & $-0.669^{*}$ \\
\hline Finland & -0.389 & $0.797 * *$ \\
\hline $\operatorname{Adj} R^{2}$ (n. observations) & $0.585(150)$ & $0.344(200)$ \\
\hline
\end{tabular}

Finally, in Table 10 the same regressions are repeated for the following sub-sample of countries: Portugal, Italy, Ireland, Greece and Spain.

Table 10. Multivariate Regression of "P" of the shares of certain financial ratios and macroeconomic variables during the pre-crisis, crisis and post-crisis periods

\begin{tabular}{lcc}
\hline & $\mathrm{P}_{(\mathrm{t})}$ & $\mathrm{P}_{(+1)}$ \\
\hline LLP/NIR & $2007-2009$ & $2010-2013$ \\
NL/D & 0.001 & $0.002^{* * *}$ \\
NL/TA & -0.001 & 0.003 \\
T1 & 0.002 & -0.003 \\
REP & 0.076 & 0.010 \\
ROAA & -0.150 & 0.140 \\
IR & $0.606^{* * *}$ & 0.070 \\
I & 0.001 & -0.0003 \\
PD\%GDP & $-0.121^{*}$ & 0.076 \\
GDPG & -0.0002 & -0.0005 \\
EYCI & $0.178^{* * *}$ & 0.060 \\
Adj $R^{2}$ (n. observations) & -0.131 & 0.012 \\
\hline
\end{tabular}

Note. $*$ denotes significance at $10 \%(\mathrm{p}<0.1), * *$ denotes significance at $5 \%(\mathrm{p}<0.05), * * *$ denotes significance at $1 \%(\mathrm{p}<0.01)$.

\section{Results}

The first study of weighted regression conducted in the absence of time lag ("Price-to-book value" year $t$ independent variables year $t$ ) has an $R^{2}$ of 0.36 in the 2007-2013 period, and thus the model shows good ability to explain the variance of the dependent variable taking into account the considered independent variables (Table 
5). The variables that help explain the trend in the prices of shares of selected banks are those related to the quality of investments, the company's profitability, and liquidity. In particular, these variables are recognized as indicators of increased flow of reserves and generally have a positive effect on the $\mathrm{P}$ of the shares. They also exert a significant effect on the positive profitability ratios and liquidity, indicating that an increase in profitability and company liquidity has positive effects on stock prices. The analysis also shows that the economic and financial equilibrium of the country has an impact on the banks: indicating, in fact, that an increase in inflation and public debt tends to carry a negative impact on the $\mathrm{P}$ of shares, while control variables such as GDP growth and the trend of the yield curve results in a significant and potentially positive impact. In particular, inflation can appear stationary on standard Augmented-Dickey Fuller (ADF) tests given its volatility (Dickey \& Fuller, 1979, 1981). Following, the Autoregressive Distributed Lag (ARDL) model is employed to estimate the log-linear equation (Pesaran \& Shin, 1997) and show that the coefficient of inflation has an expected and negative sign.

When considering the time lag $\mathrm{t}+1$ ("Price-to-book value" $t+1$ - independent variable year $\mathrm{t}$ ), the model has an $\mathrm{R}^{2}$ of 0.25 , showing a modest ability to explain the variance of the variable employed. Similar to what was found in the absence of temporal lag, this helps to explain and influence the stock prices of the banks, which are the indicator for the quality of investment, showing a direct and positive relationship between the incidence of provisions on the interest margin and the $\mathrm{P}$ of the shares. The economic viability of banks measured by their "Recurring earning power" and "Roaa" can significantly and positively influence the stock prices even with a time lag of one year. For macroeconomic variables, considering a time lag of one year, the results tend to highlight the negative impact of public debt on equity prices.

When considering fixed effects for countries in the sample (Table 6), the variables relating to the quality of investment and corporate profitability are statistically significant and positive in both specifications. The positive statistical significance and relevant indicator of the banks' capital base demonstrates that a strong balance sheet, partly as a result of the current regulations, influences stock prices. In the first model (without time lag), the results tend to highlight the negative impact of increased inflation on stock prices and the significant and positive impact of the control variables analyzed in the work. Finally, the geographic effect is significant with a positive sign for Sweden. In the second model (lag time $t+1$ ), the results tend to highlight the negative impact of public debt on equity prices, while the dummy countries, Italy and Portugal, are statistically and positively significant.

The variables that help explain the trend in share prices for the sub-sample of countries - Portugal, Italy, Ireland, Greece and Spain - are those related to the quality of investments and companies' profitability (Table 7). In particular, the trend is recognized as an indicator of increased flow of reserves and has a generally positive effect on the $\mathrm{P}$ of the shares. It also exerts a significant effect on the positive profitability ratios, indicating that an increase in profitability has positive effects on stock prices. The analysis also shows that the economic and financial equilibrium of the country has an impact on the banks: indicating, in fact, that an increase in inflation and public debt tends to carry a negative impact on the P of shares, while control variables, such as GDP growth and the trend of the yield curve, result in a significant and potentially positive impact. When considering the time lag $t+1$ ("Price-to-book value" $t+1$ - independent variable year $t$ ), the model has an $R^{2}$ of 0.27 , showing a modest ability to explain the variance of the variable employed. As to what was found in the absence of temporal lag, this helps to explain and influence the stock prices of the banks, which are the indicator for the quality of investment, showing a direct and positive relationship between the incidence of provisions on the interest margin and the $\mathrm{P}$ of the shares. For macroeconomic variables, when considering a time lag of one year, the results tend to highlight the negative impact of public debt on equity prices, while control variables such as GDP growth have a significant and potentially positive impact.

The regression study relative to the pre-crisis period and the financial crisis has an $\mathrm{R}^{2}$ of 0.52 , indicating a good ability to explain the variance of the dependent variable, while the model in the post-crisis period has an $\mathrm{R}^{2}$ of 0.32, highlighting a minor significance (Table 8). Empirical application shows how in both models the profitability of banks significantly influences the $\mathrm{P}$ of the shares with positive effects. Additionally, the negative effect on the $\mathrm{P}$ of the analyzed macroeconomic variables persists, for example the public debt trends. Among the control variables, the positive sign of the growth of GDP and the negative trend of the yield curve is noted. During the pre-crisis period and during the financial crisis the significance of the relationship is also apparent and positive, among the indicators of capitalization and liquidity, and the share price. During these periods there is a tendency for stock markets to reward better the most capitalized and liquid banks. An increase in this index seems, therefore, to be interpreted as a sign of increased stability and efficiency of the surveyed banks. However, in the post-crisis period it helps to explain and positively influences the trend of stock prices, in addition to profitability as previously highlighted, including the investment quality indicator. 
When considering fixed effects for countries in the sample, the company profitability measured by "Roaa" appears to be able to significantly and positively influence stock prices during both periods. The significance of the relationship positively persists during the pre-crisis period and the financial crisis, as do the capitalization indicator and the price of shares. The post-crisis period has a positive relationship between the quality indicator of investments and the profitability indicator measured by the "Recurring earning power" and the share price in this paper. When considering fixed effects for the countries in the sample, there is still a negative effect on the $\mathrm{P}$ value of the analyzed macroeconomic variables in the pre-crisis period and the financial crisis, such as the trend of inflation and public debt. However, in the post-crisis period the analyzed macroeconomic variables are neutral, in particular the developments in government debt, which has a highly positive statistical significance. Among the control variables is noted the positive GDP growth in both periods and the negative trend of the yield curve in the pre-crisis period and the financial crisis. In the years 2007-2009, the dummy countries France, Italy, Belgium, Austria, Greece and Portugal, are statistically significant and positive. The years 2010-2013 highlight the dummy countries Sweden, Denmark and Finland, which are statistically positively significant, while dummy countries Italy, Belgium, Greece and Portugal are statistically negatively significant. Other dummy countries are not statistically significant (Table 9).

During the pre-crisis period and during the financial crisis the profitability of banks significantly influenced the $\mathrm{P}$ of the shares with positive effects for the sub-sample of countries - Portugal, Italy, Ireland, Greece and Spain (Table 10). Among the control variables is noted the positive sign of the growth of GDP and the negative trend of inflation. However, in the post-crisis period only the investment quality indicator helps to explain and positively influences the trend of stock prices.

\section{Discussion}

This research aimed to analyze which variables influence the bank stock prices by empirically investigating a panel of European banks over periods covering the end of a period of sustained growth, to the beginning and the evolution of the financial crisis. The empirical survey provides information needed to answer the research questions specified in the introduction. First, the econometric models used return results that allow us to judge the ability of these models to explain the variance of the dependent variable both in the absence of time lag and with a time lag of one year. This makes the analysis of the results possible and significant. The estimates received by the analysis conducted for the entire period allow us to determine whether different variables affect the budget and whether they affect the stock prices of the banks analyzed. In particular, a very significant and positive relationship between stock prices and operating profitability is noted. In the econometric exercises the indicator on the quality of investment and the liquidity variables have a positive influence on banks stock prices.

In regards to the study of regression conducted on the macro-economic variables considered for the purposes of this research, equity prices seem to be more strongly influenced by the dynamics of inflation and public debt, such as a percentage of gross domestic product. The occurrence of the opposite sign suggests that the increase in inflation and the country's public debt tends to lead a negative impact on domestic banks' share prices. The neutrality of the macro-economic variables only highlights the econometric exercise conducted in the post-crisis years 2010-2013 and the fixed effects for countries.

Analysis of the data shows that, in times of crisis, the markets are proving able to read and predict, immediately, business context expressed through financial ratios, as well as the evolution of macro-economic variables considered in this paper. Consequently, this leads one to reflect that, in possible future related research could study other external phenomena such as the banking market structure, competition (Berger et al., 2009) and fusion within the banking sector (Ongena \& Roscovan, 2013; Richardson et al., 2012). The answer to the questions in this paper could generate important practical and policy implications because of the role played by banks in financing the economic system and the role played by banks' capital in allowing banks to provide credit.

\section{References}

Akella, S. R., \& Greenbaum, S. I. (1992). Innovations in Interest Rates, Duration Transformation, and Bank Stock Returns. Journal of Money, Credit and Banking, 24(1), 27-42. http://dx.doi.org/10.2307/1992789.

Allen, F. (1990). The Market for Information and the Origin of Financial Intermediation. Journal of Financial Intermediation, 1(1), 3-30. http://dx.doi.org/10.1016/1042-9573(90)90006-2.

Beccalli, E., Casu, B., \& Girardone, C. (2006). Efficiency and Stock Performance in European Banking. Journal of Business Finance and Accounting, 33(1-2), 245-262. http://dx.doi.org/10.1111/j.1468-5957.2006.01362.x

Beck, T., \& Ross, L. (2004). Stock Markets, Banks, and Economic Growth: Panel evidence. Journal of Banking 
\& Finance, 28(3), 423-442. http://dx.doi.org/10.1016/S0378-4266(02)00408-9.

Berger, A. N., Klapper, L. F., \& Turk-Ariss, R. (2009). Bank Competition and Financial Stability. Journal of Financial Services Research, 35(2), 99-118. http://dx.doi.org/10.1007/s10693-008-0050-7.

Brana, S., \& Prat, S. (2016). The effects of global excess liquidity on emerging stock market returns: Evidence from a panel threshold model. Economic Modelling, 52, 26-34. http://dx.doi.org/10.1016/j.econmod.2015.06.026.

Campbell, T. S., \& Kracaw, W. A. (1980). Information Production, Market Signaling, and the Theory of $\begin{array}{llll}\text { Financial Intermediation. Journal of } & \text { Finance, 35(4), }\end{array}$ http://dx.doi.org/10.1111/j.1540-6261.1980.tb03506.x

Cantor, R., \& Johnson, R. (1992). Bank Capital Ratios, Asset Growth, and the Stock Market. FRBNY Quarterly Review, 17(3), 10-24.

Chan, Y. S., \& Thakor, A. V. (1987). Collateral and Competitive Equilibria with Moral Hazard and Private Information. Journal of Finance, 42(2), 345-363. http://dx.doi.org/10.1111/j.1540-6261.1987.tb02571.x.

Choi, J. J., Elyasiani, E., \& Kopecky, K. J. (1992). The sensitivity of bank stock returns to market, interest and exchange rate risks. Journal of Banking and Finance, 16(5), 983-1004. Abstract retrieved from https://ssrn.com/abstract=2451139

Chu, S. F., \& Lim, G. H. (1998). Share performance and profit efficiency of banks in an oligopolistic market: evidence from Singapore. Journal of Multinational Financial Management, 8(2-3), 155-168. http://dx.doi.org/10.1016/S1042-444X(98)00025-5

Cooper, M. J., Jackson III, W. E., \& Patterson, G. A. (2003). Evidence of predictability in the cross-section of bank stock returns. Journal of Banking \& Finance, 27(5), 817-850. http://dx.doi.org/10.1016/S0378-4266(01)00263-1

Chronopoulos, D. K., Girardone, C., \& Nankervis, J. C. (2013). How Do Stock Markets in the US and Europe Price Efficiency Gains from Bank M\&As?. Journal of Financial Services Research, 43(3), 243-263. http://dx.doi.org/10.1007/s10693-012-0132-4

Czaja, M. G., Scholz, H., \& Wilkens, M. (2009). Interest rate risk of German financial institutions: The impact of level, slope, and curvature of the term structure. Review of Quantitative Finance and Accounting, 33(1), 1-26. http://dx.doi.org/10.1007/s11156-008-0104-9

Dermine, J. (1985). Inflation, Taxes and Banks' Market Values. Journal of Business Finance and Accounting, 12(1), 65-73. http://dx.doi.org/10.1111/j.1468-5957.1985.tb00079.x.

Dickey, D. A., \& Fuller, W. A. (1979). Distribution of the Estimators for Autoregressive Time Series With a Unit Root. Journal of the American Statistical Association, 74(366), 427-431. http://dx.doi.org/10.2307/2286348

Dickey, D. A., \& Fuller, W. A. (1981). The likelihood ratio statistics for autoregressive time series with a unit root. Econometrica, 49(4), 1057-1072. http://dx.doi.org/10.2307/1912517

Docking, D. S., Hirschey, M., \& Jones, E. (1997). Information and contagion effects of bank loan-loss reserve $\begin{array}{lllll}\text { announcements. Journal of } & \text { Financial }\end{array}$ http://dx.doi.org/10.1016/S0304-405X(96)00895-1

Duca, G. (2007). The relationship between the stock market and the economy: experience from international financial markets. Bank of Valletta Review, 36, 1-12.

Durai, S. R. S., \& Bhaduri, S. (2009). Stock prices, inflation and output: Evidence from wavelet analysis. Economic Modelling, 26(5), 1089-1092. http://dx.doi.org/10.1016/j.econmod.2009.04.005

Fama, E. F. (1970). Efficient Capital Market: A Review of Theory and Empirical Work. Journal of Finance, 25(2), 383-417. http://dx.doi.org/10.1111/j.1540-6261.1970.tb00518.x

Flannery, M. J., \& James, C. M. (1984). The Effects of Interest Rate Changes on the Common Stock Returns of Financial Institutions. Journal of Finance, 39(4), 1141-1153. http://dx.doi.org/10.1111/j.1540-6261.1984.tb03898.x

Giliberto, M. (1985). Interest Rate Sensitivity in the Common Stocks of Financial Intermediaries: A Methodological Note. Journal of Financial and Quantitative Analysis, 20(1), 123-126. https://doi.org/10.2307/2330682

Küçükkocaoğlua, G., Ünalmışb D., \& Ünalmış, İ. (2013). How do banks's stock returns respond to monetary 
policy committee announcements in Turkey? Evidence from traditional versus new monetary policy episodes. Economic Modelling, 35, 536-545. https://doi.org/10.1016/j.econmod.2013.07.019

Kasmana, S., Vardar, G., \& Tunç, G. (2011). The impact of interest rate and exchange rate volatility on banks' stock returns and volatility: Evidence from Turkey. Economic Modelling, 28(3), 1328-1334. https://doi.org/10.1016/j.econmod.2011.01.015

Keynes, J. M. (1936). The General Theory of Employment, Interest and Money. London. Macmillan Publishers Limited.

Lakonishok, J., Shleifer, A., \& Vishny, R. W. (1994). Contrarian Investment, Extrapolation, and Risk. Journal of Finance, 49(5), 1541-1578. https://doi.org/10.1111/j.1540-6261.1994.tb04772.x

Lancaster, C., Hatfield, G., \& Anderson, D. C. (1993). Stock price reactions to increases in loan loss reserves: A broader perspective. Journal of Economics and Finance, 17(3), 29-41. https://doi.org/10.1007/BF02920029

Lajeri, F., \& Dermine, J. (1999). Unexpected inflation and bank stock returns: The case of France 1977-1991. Journal of Banking and Finance, 23(6), 939-953. https://doi.org/10.1016/s0378-4266(98)00121-6

Macit, F., \& Topaloğlu, Z. (2012). Why Bank Market Value to Book Value Ratios so Different: Evidence From Turkish Banking Sector. Economic and Business Review, 14(2), 169-179. Abstract retrieved from https://ssrn.com/abstract $=2337975$

Merikas, A. G., \& Merika, A. A. (2006). Stock prices response to real economic variables: The case of Germany. Managerial Finance, 32(5), 446-450. http://dx.doi.org/10.1108/03074350610657454

Millon, M. H., \& Thakor, A. V. (1985). Moral Hazard and Information Sharing: A Model of Financial Information Gathering Agencies. Journal of Finance, 40(5), 1403-1422. http://dx.doi.org/10.1111/j.1540-6261.1985.tb02391.x

Modigliani, F. (1958). New Developments on the Oligopoly Front. Journal of Political Economy, 66(3), 215-232. http://dx.doi.org/10.1086/258035

Mody, A., \& Sandri, D. (2011). The Eurozone Crisis: How Banks and Sovereigns Came to be Joined at the Hip. WP/11/269. International Monetary Fund.

Mohanty, S. K., \& Song, F. (2002). International Capital Standards, Banks Portfolios and Bank Stock Risk. Applied Financial Economics, 12(7), 527-534. http://dx.doi.org/10.1080/09603100010009948

Ongena, S., \& Roscovan, V. (2013). Bank Loan Announcements and Borrower Stock Returns: Does Bank Origin Matter? International Review of Finance, 13(2), 137-159. http://dx.doi.org/ 10.1111/irfi.12002

Pacelli, V. (2007). Consulenza finanziaria e ottimizzazione di portafoglio. Bancaria Editrice, Roma.

Perry, P. (1992). Do banks gain or lose from inflation? Journal of Retail Banking, 14(2), 25-30.

Pesaran, M. H., \& Shin, Y. (1997). An Autoregressive Distributed Lag Modelling Approach to Cointegration Analysis. Centennial Volume of Ragnar Frisch, Econometric Society Monograph, edited by Strom S.A., Holly and Diamond P. Cambridge University Press.

Richardson, S., Sloan, R., \& You, H. (2012). What Makes Stock Prices Move? Fundamentals vs. Investor Recognition. Financial Analysts Journal, 68( 2), 30-51. http://dx.doi.org/10.2469/faj.v68.n2.2

Salvatore, D. (2001). International Economics. New York, John Wiley \& Sons.

Saunders, A., \& Yourougou, P. (1990). Are banks special? The separation of banking from commerce and interest rate risk. Journal of Economics and Business, 42(2), 171-182. http://dx.doi.org/10.1016/0148-6195(90)90033-9

Schollhammer, H., \& Sand, O. (1985). The interdependence Among the Stock Markets of Major European Countries and the United States: An Empirical Investigation of Interrelationships Among National Stock Price Movements. Management International Review, 25(1), 17-26. http://dx.doi.org/10.2307/40227736

Steel, P. D., \& Kammeyer-Mueller, J. D. (2002). Comparing meta-analytic moderator estimation techniques under realistic conditions. Journal of Applied Psychology, 87(1), 96-111. http://dx.doi.org/10.1037//0021-9010.87.1.96

Whalen, J. M. (1994). The Nature of Information in Commercial Bank Loan Loss Disclosures. The Accounting Review, 69(3), 455-478.

Wolff, G. (2011). Is recent bank stress really driven by the sovereign debt crisis? Bruegel Policy Contribution. 


\section{Notes}

Note 1. Although the work is the result of collaboration of two authors, section 1 and section 3.1 are attributed to Vincenzo Pacelli, section 2 and section 3.2 are attributed to Elisabetta D'Apolito, while section 3.3, section 4 and section 5 are jointly developed.

Note 2. The quotient price-to-book value $(\mathrm{P})$ is the ratio between the market capitalization of the company and the value of the equity of the same in the financial statements (book value).

Note 3. The choice of specifications, dependent and independent variables depended on the will to obtain significant econometric as well as sufficiently robust estimates. Objective addressed, as highlighted in the next paragraph.

Note 4. Recent research (Steel \& Kammeyer-Mueller, 2002) have shown that the weighted regression (WLS) is not affected by multicollinearity and heteroskedasticity problems.

Note 5. A dummy country is included, since fixed effects led us to exclude the intercept of the model estimates in order to not generate multicollinearity.

\section{Copyrights}

Copyright for this article is retained by the author(s), with first publication rights granted to the journal.

This is an open-access article distributed under the terms and conditions of the Creative Commons Attribution license (http://creativecommons.org/licenses/by/4.0/). 